\title{
Using New Means of Technology during the Penal Proceedings in Romania
}

\author{
El uso de nuevos medios tecnológicos \\ en el procedimiento penal en Rumanía
}

O uso de novos meios de tecnologia no processo penal da Romênia

Delia Magherescu ${ }^{1}$

Gorj Bar Association - Romania

delia_magherescu@yahoo.com

http://orcid.org/0000-0003-0939-1549

\begin{abstract}
AвSTRACT: The new legal framework created since 2014 while the new Code of penal procedure entered into force in Romania has opened a different way of approaching the justice in criminal matters. In such a legal context the judicial bodies are more accustomed with the idea of using the new means of technology in such a way not to infringe the parties' procedural rights during the penal trial knowing the fact that using illegal protocols signed by the prosecutor offices with the Romanian Intelligence Service was prohibited by the Constitutional Court of Romania. In the current paper, a qualitative research has been carried out on both legislative and jurisprudence items regarding the new means of technologies currently used in the penal justice. The main purpose of the paper is to analyze the effect of the new means of technology including the use of digital evidence which occur in the penal trial in Romania as well as to discuss the legal consequences they produce in practice. Some practical points of view have been highlighted taking into account the new means of technologies' efficiency. Moreover, in order to improve the penal procedure into force certain proposals of de lege ferenda have been provided.
\end{abstract}

KEYWORDs: means of technology; digital evidence; procedural issues; respecting parties' rights; constitutional limitation.

1 Doctor in Law since 2005 awarded at the State University of Moldova, Republic of Moldova. 
Resumen: El nuevo marco jurídico creado en Rumanía en 2014, con la aprobación de un nuevo Código de procedimiento penal, ha transformado la forma de aproximación a la justicia penal. En este contexto jurídico, los entes jurisdiccionales se han ido adaptando a usar nuevos medios tecnológicos en el marco de los procedimientos penales sin infringir los derechos procesales de las partes, tras la prohibición, por parte del Tribunal Constitucional, del empleo de protocolos ilegales firmados por las fiscalías con el Servicio de Inteligencia de Rumanía. En este trabajo se desarrolla una investigación cualitativa, que analiza materiales legislativos y jurisprudenciales, sobre los nuevos medios tecnológicos que se usan en la justicia penal. El objetivo principal del artículo es analizar los efectos de esos nuevos medios tecnológicos empleados en el procedimiento, incluidas las pruebas digitales, así como discutir las consecuencias jurídicas que producen en la práctica. En este sentido, se ponen de relieve algunos puntos de vista prácticos que destacan la eficiencia de los nuevos medios tecnológicos. Junto a ello, se hacen algunas propuestas de lege ferenda para mejorar el procedimiento penal en vigor.

Palabras-clave: medios tecnológicos; prueba digital; cuestiones procesales; garantía de los derechos de las partes; límites constitucionales.

Resumo: O novo quadro legal criado em 2014, quando da entrada em vigor do novo Código de Processo Penal na Romênia, deixou aberta uma nova forma de aproximação à justiça criminal. Nesse contexto legal, as autoridades judiciais estão mais habituadas a usar os novos meios tecnológicos de modo a não infringir os direitos processuais das partes durante o julgamento, sabendo que o uso de meios ou protocolos ilegais, assinados pela acusação em conjunto com o serviço de informação da Romênia, é proibido pelo Tribunal Constitucional da Romênia. No presente estudo, analisam-se alguns aspectos dos novos meios tecnológicos que são atualmente usados na justiça penal, tanto no plano legislativo como jurisprudencial. O propósito principal deste estudo é analisar o efeito dos novos meios tecnológicos, incluindo a prova digital, utilizados em julgamentos criminais na Romênia, bem como discutir as consequências legais da sua utilização. Alguns aspetos práticos foram sublinhados tendo em conta a eficiência desses novos meios tecnológicos. Apresentam-se ainda algumas propostas de lege ferenda de modo potenciar a realização do processo penal.

Palavras-chave: meios tecnológicos; prova digital; questões processuais; direitos processuais; limites constitucionais. 


\section{INTRODUCTION}

Romania has followed a well structured way determined by the judicial authorities' goals to achieve the European general legal framework of reorganizing the entire judicial system in criminal matters in accordance with the democratic values since January 1, 2007 while it joined the European Union as a Member State. Nevertheless, that way was not a smooth one due to the fact that Romania is coming after a long and difficult transition period from the totalitarian regime to democracy and the rule of law principles. In this both social and legal context, it is relevant for the judicial authorities the European programs of harmonizing the home legislation in criminal matters to the European acquis. These efforts have been also made previously more particularly during the ante-adhesion period, but the real reformation of the judicial system in criminal matters started since 2007. From this reason, I appreciate the "judicial spring" has begun in 2014 once the Law no. 135/2010 on the new Code of penal procedure entered into force. ${ }^{2}$ Thus, the long time-period states a difficult itinerary but necessary in order for the Romanian authorities to reach the proposed scope.

The new Code of penal procedure has the main role of regulating new judicial institutions, one of them leads with the implementation of the new means of technology in the justice in criminal matters. As it will be highlighted in the current paper, the new means of technology used in the investigation of penal cases created the opportunity to achieve the most appropriate procedure of solving the penal cases, on the one hand. On the other hand, there were some special techniques of criminal investigation that produced an interference in the parties' fundamental rights exercised during the penal trial. They have been more reflected in the defendant's procedural rights during the criminal proceedings.

It is well known at the moment one of the objectives of the penal trial is that of implementing the digital world in the penal proceedings as a result of adapting the new legislation in the field of penal procedure law

2 Law no. 135/2010 on the Code of penal procedure of Romania, published in the Romanian Official Journal no. 486 of 15 July 2010, entered into force on February 1, 2014. 
to the contemporary social changes. For the Romanian judicial system in criminal matters it was very much a desideratum. Nevertheless, it is one of the legal ways of finding adequate solutions for the judicial and technical issues the judicial bodies are still confronted with. ${ }^{3}$

In the field of jurisprudence, the main objective is that of harmonizing the modern technical means of investigation in the penal cases with respecting the participants' fundamental rights during the penal proceedings. From this point of view, the doctrine has emphasized the idea of avoiding two issues both by the legislator and the judicial bodies called to apply the provisions of the Code of penal procedure in their activity of solving the penal cases.

Thus, on the one hand the formalism of pronouncing the judicial solutions which are impossible to apply in practice must be avoided. ${ }^{4} \mathrm{On}$ the other hand, the formalism of pronouncing practical and pragmatic solutions which do not assure respecting the fundamental parties' rights as well. ${ }^{5}$

In carrying out the current research paper, I analyzed the doctrinaire points of view as well as the jurisprudence references gathered from the law courts' decisions pronounced in penal cases. They allowed me to point out some pertinent statements on the most relevant aspects the means of technology occur in the penal trial in Romania.

\section{Digital eVidence: AN OVervieW}

During the investigation phase of the penal trial, the investigation bodies' scope is that of gathering evidence in order to find the truth in the penal cases they were invested with. Actually, the scope of the investigation phase must be viewed in accordance with the scope of the entire penal trial due to the fact that the decision pronounced will reflect the truth if it is based on evidence.

\footnotetext{
3 Suian, Mihai, Unele probleme privind folosirea probelor digitale în procesul penal, Bucharest: Doctrina si Jurisprudenta, No. 1/2019, p. 135.

4 Ibidem.

5 Ibidem.
} 
Featured as being a new concept of the penal trial ${ }^{6}$, the digital evidence becomes more associated with a defensive mechanism deploying by judicial bodies who pay their attention upon digital forensic investigation. Most of the time, the digital evidence is associated with cybercrime as a new type of evidences. ${ }^{7}$ Its main feature leads to the electromagnetic record the digital evidence exists on "easy to modify and copy, hard to understand the content directly without the conversion process, and not easy to retains the original state". 8

The process of adapting the legislation in the field of digital evidence is an international issue ${ }^{9}$ as a consequence the home legislation of penal procedure law is frequently out of date by the practical solutions regarding the legality of administering evidences or even investigating the crime scene in the digital area. ${ }^{10}$

Administering the digital evidence during the penal proceedings in Romania is strictly approached due to the fact that the new Code of penal procedure of 2014 has failed in remedying the gaps the previous penal procedural legislation was confronted with. In spite of this inconvenient, the jurisprudence reacted and identified appropriate solutions.

First of all, the judicial bodies have stated that the digital evidence is used in the penal cases having as object the serious crimes. The degree of their social danger is analyzed both from the point of view of the criminal means and modus operandi used by the defendants as well as from the point of view of the legal consequences produced because of

6 Rekhis, Slim; Boudriga, Noureddine, Visibility: A Novel Concept for Characterizing Provable Network Digital Evidences, International Journal of Security and Networks, No. 4/2009, pp. 234-245.

7 Sun, Jia-Rong; Shih, Mao-Lin; Hwang, Min-Shiang, A Survey of Digital Evidences Forensic and Cybercrime Investigation Procedure, Taichung: International Journal of Network Security, Vol. 17, No. 4/ 2015, p. 498.

8 Ibidem.

9 Suian, Mihai, op. cit., p. 135.

10 Britz, Marjie T., Computer Forensics and Cyber Crime: An Introduction, New Jersey: Perason Education, 2013, pp. 26-28. 
the crimes committed. ${ }^{11}$ Most of them occur in the digital environment or by technical means which involve a digital system.

Secondly, the fundamental characteristic of the general theory of administering evidence in the penal trial is that of material feature of the means of evidence. In other words, digital evidence contains trances of committing offences, but they have an immaterial character due to the fact that they exist exclusively within the digital environment. Nevertheless, the only one way for the digital evidence to be administered in the penal trial is related to the traces of committing offences which must be stocked on an information support of stocking digital data. This means that the digital evidence must be sampled from an informatics system. This activity is provided to the forensics experts in the field of the information technology.

By definition, the Code of penal procedure regulates the digital data as being "any representation of facts, information and concepts under an adequate form of processing it within an informatics system including a program which determines carrying out a function by an informatics system". ${ }^{12}$ In accordance with the legislative definition, there are several critiques also occurred by doctrine. One of these has been pointed out by prof. Suian who stated the concept is not provided clearly enough, thus the digital data also mean "any representation of facts, information or concepts, which are recovered in an informatics system or on stocking support". ${ }^{13}$

Thirdly, from the procedural point of view, in order to access the information system the digital data which must be used in the penal trial are stocked on, as well as to administer them the judge's judicial authorization is necessary. The procedure is justified by the fact that through this method of forensics activity a series of encroachments in the individual's right to private life is accomplished. ${ }^{14}$ This is a serious drawback as long as the right to the private life is established both by

11 Miclea, Damian, Cunoasterea crimei organizate, Ploiesti: Pygmalion Publishing House, 2001, pp. 153-249.

12 Article 138 (5) Code of penal procedure.

13 Suian, Mihai, op. cit., p. 136.

14 Udroiu, Mihail; Slavoiu, Radu; Predescu, Ovidiu, Tehnici speciale de investigare in justitia penala, Bucharest: C.H. Beck Publishing House, 2009, p. 3. 
the European Convention on Human Rights ${ }^{15}$ and the European Court of Human Rights' jurisprudence.

In this respect, the European Court of Human Rights of Strasbourg pronounced several sentences against Romania because of the infringing Article 8 of the European Convention on Human Rights on respecting the right to the private life, such as Sentence of 21 April 2009: the case Raducu v. Romania ${ }^{16}$, Sentence of 28 September 2004: the case Sabou and Pircalab v. Romania ${ }^{17}$, Sentence of 30 June 2009: the case Burzo v. Romania $^{18}$, Sentence of 16 July 2013: the case Balteanu v. Romania ${ }^{19}$.

The Romanian Constitution also regulate the principle of respecting the right to the private life at the Article 26 thereof which devotes the individuals' right to the private life. The public authorities are responsible for respecting the fundamental right as stated above as

15 Article 8 of the European Convention on Human Rights of 1950 safeguards the individual's right to respect the private and family life and states that: "Everyone has the right to respect for his private and family life, his home and his correspondence. There shall be no interference by a public authority with the exercise of this right except such as is in accordance with the law and is necessary in a democratic society in the interests of national security, public safety or the economic well-being of the country, for the prevention of disorder or crime, for the protection of health or morals, or for the protection of the rights and freedoms of others". Council of Europe, Cedex, Strasbourg. https://www.echr.coe.int/ Documents/Convention_ENG.pdf

16 Sentence of 21 April 2009 of the ECHR, available online at: https://jurisprudentacedo.com/Raducu-c.-Romaniei-Interceptare-convorbiri-telefonice-Viata-privata.html (accessed on 16 May 2019)

17 Sentence of 28 September 2004 of the ECHR, published in the Official Journal of Romania, no. 484 of 8 June 2005, available online at: https://jurisprudentacedo.com/Sabou-si-Pircalab-contra-Romania-Interzicerea-exercitarii-drepturilor-familiale-Condamnare-penala-Conditii.html (accessed on 16 May 2019)

18 Sentence of 30 June 2009 of the ECHR, available online at: https://hudoc. echr.coe.int/eng\#\{\%22fulltext\%22:[\%22calmanovici\%22],\%22languageisocode\%22:[\%22RUM\%22],\%22documentcollectionid2\%22:[\%22GRANDCHAMBER\%22,\%22 CHA MBER\%22],\%22 itemid\%22:[\%22001$123471 \% 22]\}$ (accessed on 16 May 2019)

19 Sentence of 16 July 2013 of the ECHR, available online at: https://hudoc. echr.coe.int/eng\#\{\%22fulltext\%22:[\%22calmanovici\%22],\%22languageisocode\%22:[\%22RUM\%22],\%22documentcollectionid2\%22:[\%22GRANDCHAMBER\%22,\%22 CHA MBER\%22], \%22 itemid\%22:[\%22001$142106 \% 22]\}$ (accessed on 16 May 2019) 
well as their family right. ${ }^{20}$ Last but not least, the Code of penal procedure regulates at the Articles 138-153 thereof the chapter on the topic of special methods of surveillance and investigation in penal cases. Both the international and national legal framework provide the mechanism of derogation in exceptional situations.

On the one hand, the special surveillance of people exercised by the law enforcement using special technical means is considered by doctrine as being a real encroachment in their right to the private life. ${ }^{21}$ On the other hand, the common surveillance carried out in public places regarding the individuals' activity during a short period of time does not mean entirely an encroachment in their private life as the European Court of Human Rights' jurisprudence understands to state. ${ }^{22}$

\section{ENCROACHMENTS IN THE INDIVIDUAL'S RIGHT TO THE PRIVATE LIFE}

The new Code of penal procedure created ab initio the judicial investigation authorities' possibility to sign protocols having as object the cooperation between the investigation bodies and the intelligence services' officers. De facto, the last ones have been entitled to carry out specific acts of investigation by special means of technology provided outside the judge's approval. A long period of time they were into force, till the beginning of 2016 while the Constitutional Court of Romania sanctioned them and decided upon their unconstitutionality and subsequently their illegality. ${ }^{23}$ The Constitutional Court emphasized that the systematic

20 Article 26 of the Constitution of Romania republished in the Official Journal of Romania, no. 669 of 22 September 2003.

Udroiu, Mihail; Slavoiu, Radu; Predescu, Ovidiu, op. cit., p. 7.

22 nia, published in the Romanian Official Journal, no. 283 on 30 April 2009, available online at: https://hudoc.echr.coe.int/eng\#\{\%22fulltext\%22:[\%22calmanovici\%22],\%22documentcollectionid2\%22:[\%22GRANDCHAMBER\%22,\%22CHAMBER\%22],\%22itemid\%22:[\%22001-122630\%22]\}（accessed on 16 May 2019)

Decision no. 51 of 16 February 2016 of the Constitutional Court of Romania, published in the Official Journal no. 190 of 14 March 2016, available online at: https://www.ccr.ro/files/products/Decizie_51_2016.pdf; Decision no. 244 of 6 April 2017 of the Constitutional Court of Romania, published in the 
gathering of information by the intelligence services officers regarding the defendants' activity during the penal trial in particular in the investigation phase as well as recording them through the technical means of surveillance is an encroachment in the people private life. As a consequence, this kind of activity is performed through violation of the Article 8 of the European Convention on Human Rights. Actually, the Article 8 thereof permits the judicial authorities to derogate from this principle in special cases and for particular conditions expressly regulated by the Code of penal procedure. This means that the unique authority entitled to approve the technical surveillance during the investigation phase is the judge. Any other procedures parallel to the ordinary judicial procedure which would involve the other public law enforcement agencies have been declared unconstitutional. In this context, the only one question can be asked: what is happened with the judicial decisions pronounced previously which were based on these protocols? Do the decisions in penal cases produce consequences? Are they still into force? The answer cannot be a positive one due to the reason that has already stated earlier and provided by the Constitutional Court as well. The consequences of the illegal procedure adopted by the Romanian judicial authorities must be viewed in the penal procedure law's low level of quality, the lack of its clarity and precision as well as the predictability and accessibility, which all in all created the premises for infringing the defendants' procedural rights independent of their information. ${ }^{24}$

De iure, the encroachments exercised by the other public authorities, which are not legally entitled to carry out the investigation activity during the penal trial means a limitation of the defendants' right to private life and must be subsequently prohibited by the Constitutional Court. In these cases, it imposed a constitutional limitation in accordance with the European Convention on Human Rights' provisions and the

Official Journal no. 529 of 6 July 2017, available online at: https://www.ccr. ro/files/products/Decizie_244_2017.pdf (accessed on 16 May 2019)

24 Selea, Mircea Mugurel, Application of the art. 102 (2) and (3) of the Criminal Procedure Code in relation to special surveillance measures listed under the art. 138 (1) (a) and (c) of the Criminal Procedure Code enforced before the publication in the Official Journal, Revista de Stiinte Politice, Craiova: Universitaria Publishing House, Issue no. 53/2017, pp. 104-110. 
European Court of Human Rights' jurisprudence. Nevertheless, the constitutional limitation is not an absolute one, thus the defendants' surveillance can be decided by the judge in cases in which it is regulated by the penal procedure law, it is looking for a legitimate scope, it is necessary in a democratic society and it is proportionally to the proposed scope. ${ }^{25}$

At the international level, doctrine has also been involved in finding solutions to warrants for videotape surveillance issuable despite the lack of statutory authority. ${ }^{26}$ On this topic, the author highlighted that the Constitution and the provisions of Code of penal procedure "permit electronic eavesdropping by wiretaps or mechanical listening devices pursuant to a special search warrant. No constitutional or statutory authority exists, however, for the issuance of warrants permitting videotape surveillance." ${ }^{27}$

This concept also leads to the defendants' right to be informed upon request during the investigation phase on the evidence the judicial accusation is based on. ${ }^{28}$ Knowing this feature, the defendant will be advised by his advocate regarding the legal possibilities of defense ${ }^{29}$ as well as to combat the accusation by means of penal procedure law and propose evidence in defense. Otherwise, the restriction of defendant's procedural rights during the investigation phase will be analyzed in accordance with the European provisions. ${ }^{30}$ Such conditions allow the European instance to appreciate the entire de facto circumstances of penal case as well as to restrain the infringement of the guaranteed right. ${ }^{31}$ This is because the European Convention in particular the Article 8 thereof refers especially to the encroachments came from the public state authorities. In this matter, both doctrine and the European jurisprudence pointed out that this

25 Article 11 Code of penal procedure.

26

Conners, Kerry B., Warrants for Videotape Surveillance Issuable Despite Lack of Statutory Authority, St. John's Law Review: vol. 54, no. 4/1980, pp. 790-795.

27 Idem, pp. 790-791.

28 Jaidev, Ms, Brady Ruling, 1963 U.S. Supreme Court: Sifting from being heard to open trial American and Indian Context, International Journal of Research, vol. 05, Issue 01/2018, p. 1753.

29 Magherescu, Delia, Recunoasterea vinovatiei si aplicarea pedepsei, Bucharest: Hamangiu Publishing House, 2019, pp. 29-32.

${ }^{30}$ Idem, p. 6.

31 Udroiu, Mihail; Slavoiu, Radu; Predescu, Ovidiu, op. cit., p. 10. 
principle is also applied in cases in which there are encroachments came from the natural persons upon the individuals' right as it is guaranteed by the European Convention. The syllogism consists in the fact that the state through its judicial authorities is obliged to protect their private file. ${ }^{32}$

Doctrine also created a particular framework on the victims' rights in criminal proceedings. ${ }^{33}$ An antagonistic issue arose in the cases in which defendants turn into victims of the judicial authorities because of the encroachments in their private life. The dual position of the defendant, as being also a victim in the penal trial, could be viewed as an unbalance between the goals of the investigation bodies and the serious human rights violations. ${ }^{34}$ Moreover, in the stated nexus, a paradoxical relation has been highlighted between penal trial and human rights. ${ }^{35}$ Francoise Tulkens explains "the offensive role of human rights, which allows recourse to criminal remedies under the circumstances and conditions described above, inevitably entails other cascade effects in relation to the ECHR." ${ }^{36}$

Interpreting the rules of penal procedure law, the encroachments in the defendants' private life are related to those communications which are characterized by the presumption of confidentiality. From this point of view, certain theories can be advanced. One of them refers to the defendant's intimate-familial area, which exceeds common criteria which involve identifying the confidential communications. The second theory is featured in close of the defendant's nature of communications. It supposes more the subjective impact upon the defendant's right to private life violation as well as increases his status of the victim of penal trial. As it has been already pointed out above, the victimization of defendant is actually made with the public authorities' indirect consent.

32 Trechsel, Stefan; Summers, Sarah J., Human Rights in Criminal Proceedings, Oxford: Oxford University Press, 2009, pp. 523-548.

33 Sanchez, Juan Carlos Ochoa, The Rights of Victims in Criminal Justice Proceedings for Serious Human Rights Violations, Brill/ Martinus Nijhoff, 2013, pp. 71-93.

34 Ibidem.

35 Tulkens, Francoise, The Paradoxical Relatsh between Criminal Law and Human Rights, Journal of International Criminal Justice, vol. 9, Issue 3/2011, pp. 577-595.

36 Idem, p. 591. 
In opposition to the principles of the non-infringement of the defendants' procedural rights during the investigation phase ${ }^{37}$, both theories are not exempted from criticisms. The first theory has the disadvantage of excluding from the defendants' private life their communications held in a public place, while the second one uses the subjective element which is difficult to appreciate definitely. ${ }^{38}$ As a consequence, another criterion based on adequate theory must be provided which would determine a new feature of the presumption of confidentiality more suitable for the entire principles of penal trial.

\section{Constitutional limitation}

Using discretionary the means of investigation a special attention upon the digital evidence has created the reaction of the Constitutional Court which decided on the exceptions of unconstitutionality of the Code of penal procedure. In this regard, a particular feature has been created upon Article $142(1)^{39}$ and Article $145^{40}$ thereof.

In relation to the first case, the Constitutional Court of Romania pronounced Decision no. 51 of 2016 on the admitting unconstitutional exception of Article 142 (1) Code of penal procedure. The Court stated that the legal provision infringe Article 1 (5) of the Constitution regarding the Romanian state, Article 20 on the international treaties regarding the human rights Romania is part of, Article 21 on the free access to justice, Article 53 on the restricting fundamental citizens' rights and liberties as well as Article 6 and Article 8 of the European Convention on Human Rights which regulate the provisions on fair trial ${ }^{41}$ and the fundamental right on respecting private and family right. The Court also decided that the Code of penal procedure regulates expressly the

37 Magherescu, Delia, op. cit., pp. 54-55.

38 Udroiu, Mihail; Slavoiu, Radu; Predescu, Ovidiu, op. cit., p. 20.

39 Decision no. 51 on 16 February 2016 of the Constitutional Court of Romania, published in the Official Journal no. 190 of 14 March 2016.

40 Decision no. 244 on 6 April 2017 of the Constitutional Court of Romania, published in the Official Journal no. 529 of 6 July 2017.

41 Magherescu, Delia, op. cit., pp. 21-34. 
special means of investigation including the special methods of technical surveillance. Article 138 (1/a-e) Code of penal procedure enumerated those related to: intercepting the communications or any kind of longdistance communication; accessing an informatics system; video-audio surveillance; localizing or surveying by technical means; obtaining data of the persons' financial transactions. However, the Article 142 (2) Code of penal procedure states that the prosecutor does execute technical surveillance or can dispose they may be executed by the police investigation officers or by the other specialized state's bodies.

Excepting the provisions of Article 142 (1) Code of penal procedure, there is no national regulation which provides the other state's bodies to intercept or execute a technical surveillance warrant. As a consequence, such provision could be regulated only by ordinary law in a predictable and clear legal framework, but not by an "infralegislative legislation" ${ }^{42}$, such as the administrative one due to the fact that they are featured by a high degree of instability and inaccessibility. The special means of investigation are also more efficiently both for the person's involved, the defendant, for the investigation bodies and for the courts of law. Otherwise, there is the danger of infringing abusively the fundamental citizens' rights basically for the rule of law. In this regard, the constitutional standard of protecting private, family and intimate life as well as the correspondence secret impose that their limitation to be made in an appropriate legal framework which states expressly, clearly and predictably the qualified bodies to execute such activities which mean encroachments in the defendants' private life.

In accordance with the Constitutional Court's decision, the judicial bodies invested by law with such abilities are the prosecutors and the judicial police investigation bodies. ${ }^{43}$ It does not permit to include in the Article 142 (1) Code of penal procedure provision the expression "the other specialized state's bodies" which are not defined or specified within the Code or another ordinary law.

42 Decision no. 51 on 16 February 2016 of the Constitutional Court of Romania, published in the Official Journal no. 190 of 14 March 2016.

43 In conformity with Article 30 Code of penal procedure corroborated with Article 55 (5) thereof. 
The second case occurs on the Constitutional Court Decision no. 244/2017 regarding the unconstitutional exception of Article 145 Code of penal procedure invoked in Case no. 4821/1/2015 in front of the High Court of Cassation and Justice which opined that the technical surveillance included means of evidence that supposed serious encroachments in the defendant's private life, right already protected by Article 26 and 28 of the Romanian Constitution. The High Court of Cassation and Justice appreciated that the verification of these means of investigation legality could be done exceptionally by incidental way in particular cases. In this context, the supreme court stated there is no legal provision which permits defendants to request the verification of legality of administering evidence in accordance with Article 340 Code of penal procedure.

Constitutional Court emphasized that the unconstitutional exception invoked referred to the "rights and liberties judge's conclusion pronounced on the means of technical surveillance cannot be appealed". For this reason, the parties involved in a penal trial cannot appeal the conclusion pronounced by the judge of rights and liberties on the means of technical surveillance. The Court's jurisprudence states that in principle the measure infringe the defendant's procedural right or a legitimate interest he is entitled to intimate the court of law in order to invoke the damage suffered and remove it even if the procedure implies exercising appeal. As pointed out by the European Court of Human Rights' jurisprudence, from the point of view of the legal nature, the right to appeal provided by Article 13 European Convention of Human Rights is a subjective procedural right which guarantees the access to justice in front of the court of law that may reestablish the legal situation.

Regarding the case of Romania, the Court's decisions highlight that its jurisprudence in the matter of process remedy against the means of technical surveillance has known an evolution during the last period of time. Initially, the European Court of Human Rights observed that, in accordance with the home law, a person whose legitimate interests have been infringed by using technical means of investigation could request the court of law to declare illegality of the means of intercepting the private communications and obtain 
compensations ${ }^{44}$. Subsequently, the European Court of Human Rights stated that Romania did not provide an example of the law courts' jurisprudence which demonstrates the appeal efficiency in this matter. Moreover, the Court also stated that the civil appeal declared by entitled person to involve the state's responsibility in order to obtain compensations does not permit a control of legality of intercepting the private communications and a decision to dispose destroying them. This means that there is no effective control in accordance with Article 8 of the Convention.

In conclusion, in the field of the technical means of surveillance that really mean an encroachment in the defendants' private life, an a posteriori control can exist in purpose to verify the legal conditions regulated and the modality of executing the technical surveillance warrant, as provided by Article 142-144 Code of penal procedure. Both the constitutional and European jurisprudence impose the positive state's obligation having as object the regulation of "effective appeal" which allows removing possible infringements of the defendants' fundamental rights and liberties. It is appreciated that in absence of such an appeal in the penal proceedings means a violation of the obligation, in particular of the Article 21 of the Constitution and Article 13 of the European Convention.

Doctrine also has been involved in how these provisions suppose changing the nature of the defendants' presumption of innocence while they are surveyed and how the legislator can rewrite the human rights and regulate the use of surveillance technologies in such a matter not to imply an encroachment in the defendants' private life. ${ }^{45}$ The author points out that "the widespread use of surveillance technologies and their huge technological potential emphasize the need to focus on the relationship between surveillance and the presumption of innocence.

44 Sentence of 16 July 2013 of the ECHR: Case Balteanu v. Romania, available online at: https://hudoc.echr.coe.int/eng\#\{\%22fulltext\%22:[\%22calmanovici\%22],\%22languageisocode\%22:[\%22RUM\%22],\%22documentcollectionid2\%22:[\%22GRANDCHAMBER\%22,\%22CHAMBER\%22],\%22itemid\%22:[\%22001-142106\%22]\} (accessed on 16 May 2019)

45 Galetta, Antonella The changing nature of the presumption of innocence in today's surveillance societies: rewrite human rights or regulate the use of surveillance technologies?, Belfast: European Journal of Law and Technology, Vol. 4, No. $2 / 2013$. 
The link between surveillance and the presumption of innocence is very close, considered that surveillance measures are deployed to control, detect, deter and prevent crime." ${ }^{46}$

As a consequence, using the special means of technological investigation by inappropriate state's bodies other than the judicial ones turns into the erosion of the defendants' presumption of innocence during the penal proceeding $\mathrm{s}^{47}$ especially in cases in which the secret services use this kind of technology in executing the prosecutor's decision.

\section{Particularities of the procedure involving digital INVESTIGATION}

The procedure in penal cases of digital investigation involves priory the informatics or digital search and the investigation of the "crime scene" of the informatics offences. The legal basis of the digital search is provided by the Code of penal procedure, Article 168 thereof. It is a conclusive forensic method which consists in investigating a digital system or a support that stocks information data in purpose to find and gather digital evidence necessary in solving the penal cases. The main purpose of digital search is given by drawing digital evidence - electronic information having conclusive value, preserving the digital data which contain traces of informatics offences in those cases in which there is the danger of losing or modifying them.

The penal procedure of digital search presents the following characteristics:

- It represents a special technique of forensic investigation in criminal matters. Doctrine has appreciated the digital search alongside with accessing a digital system, regulated by Article 138 (1/b) and (3) Code of penal procedure represents encroachments in the defendants' right to the private life, as it has been already pointed out in the previous section of the current paper. The procedure neither involves the penetration of the defendants' domicile, nor excludes it. In accordance with the previous penal

\footnotetext{
46 Ibidem.

47 Ibidem.
} 
procedural regulation, provided by Law no. 161/2003, the digital search was disposed beforehand taking the digital system within the domiciliary search.

- The necessity to protect the defendants' private life directs to imposing some additional guarantees in cases of digital search. The legislator has stated in such cases applying the same guarantees as in cases of domiciliary search.

- The digital search is disposed in cases in which there are reasonable reasons for the investigation bodies to consider that the digital system or the support of stocking the digital data that is subject to the digital search contains digital evidence regarding the offence committed and the judicial measure is necessary and proportional to the proposed judicial purpose.

Article 168 (1) Code of penal procedure regulates "digital system search or a support of stocking the digital data means the investigation method of discovering, identifying and gathering digital evidence stocked in a digital system materialized through technical means and adequate proceedings of assuring the integrity of such information therein".

During the investigation phase, the competence in disposing the procedure of digital search belongs to the judge of rights and liberties who can admits the prosecutor's request of carrying out the digital search. Procedural speaking, the prosecutor submits his request with the penal case to the judge of rights and liberties, who will decide immediately in the council room in the presence of the prosecutor. In cases in which the judge considers the request is founded will admit it and dispose allowing the digital search through issuing the search warrant. The decision is definitively and cannot be subject to appeal.

The search warrant contains the legal elements, as provided by the Code of penal procedure. They consist in mentioning the scope it has been issued for; the digital system or the support of stoking the digital data which must be searched; the defendant's name if known.

A particular situation could be arisen in cases of digital search. There is the possibility for the forensic investigators to find that the digital data the forensic investigators look for are contained by another digital system which can be accessed from the initial system. In this case, the prosecutor disposes immediately the preserving and copying them. The procedure requires the prosecutor will solicit completing the search warrant on the new digital system. 
In those cases of carrying out digital search the investigation bodies must pay a special attention on this procedure including the number and size of digital system, the nature of wireless network and internal network as well in order to maintain unimpaired the digital data content. In this sense, the digital evidence will not be distorted or even modified. The detailed procedure of carrying out the digital search is provided by the Introductory Guide of Applying Legal Regulations regarding the Digital Criminality, drawing up by the Ministry of Communications and Information Technology $y^{48}$ in $2004 .{ }^{49}$ It provides aspects regarding the procedure of taking the digital system, shutting down the system, labeling the components, protecting against the data modification as well as transporting them to the laboratory.

Within the digital search the forensic investigators will proceed to copying the digital data gathered from the digital system. It is advisable for the investigation bodies to proceed in double-sample copy, one of them will be sealed as a witness-evidence, and another one will be used in purpose to extract the digital data. The memory supports the digital data are copying on as well as the envelopes they are introduced in will be signed by the forensic investigators who participated in the digital search.

Despite the penal procedure of digital search, the interest occurs on the person entitled to carrying out it. The code of penal procedure regulates that the competence in carrying out the digital search belongs to the forensic investigator that is working within the judicial bodies. The activity of digital search is made in the presence of the prosecutor.

\section{JURISPRUDENTIAL REFERENCES}

Case 1:

Once the Constitutional Court pronounced on the illegal use of defendants' surveillance technologies by the other state's bodies than the judicial ones, the courts of law in penal matters were entitled to decide

48 The Introductory Guide of Applying Legal Regulations regarding the Digital Criminality, Bucharest: INTERNEWS RITI dot-GOV, 2004.

49 Olteanu, Gabriel Ion; Ruiu, Marin, Tactica criminalistica, Bucharest: AIT Laboratories Publishing House, 2009, pp. 142-146. 
upon the illegality of such administrative measures. Regarding this aspect, the law courts' jurisprudence is very rich in decisions pronounced in cases in which such illegal surveillance technologies were used.

Considering the fundamental principles of respecting private life and human rights entirely, the activity of investigation carrying out through infringing the defendant's rights supposes the nullity of such activity. Regarding the principle of administering digital evidence they must be gathered through respecting legal provisions. ${ }^{50}$ During the pretrial court the defendant has formulated exceptions on the legality of administering digital evidence as well as on carrying out the activity of the investigation phase by the General Prosecutor Office attached to the High Court of Cassation and Justice - Direction of the Investigating Organized Crimes and Terrorism. The judge of preliminary court understood that the defendants were sent to trial due to committing the offence of initiating an organized criminal group incriminated by Article 367 (1) and (2) penal Code, offence of trafficking of minors incriminated by Article 211 (1) and (2) penal Code and trafficking of human beings also incriminated by penal Code at the Article 210 (1/a and b) thereof.

The prosecutor retained the fact that during the period of time between 2011 and 2016 the defendants set up an organized criminal group which was involved in "recruiting, transporting, accommodating and sexual transnational exploiting of 5 minor women between the age of 15 and 17 years old and a number of 24 major women which came from disadvantaged families having a low level of education, with a very precarious material situation and different vulnerabilities". ${ }^{51}$

The prosecutor also stated in the indictment act that the group's leader coordinated and surveyed entire criminal operation consisting in the women' sexual exploitation which took place in Italy. The women were allured through the pretext of being engaged in well-paid labors in the destination country where they will receive a huge salary. Actually, the entire amount of money proceeded from criminal activities were sent in the defendants' home country and distributed among the group

\footnotetext{
50 Penal Decision no. 18 of 15 February 2017 of the Court of Law of Iasi, available online at: http://portal.just.ro/99/Lists/Jurisprudenta/DispForm.aspx?ID=378

51 Ibidem.
} 
members. It has been established that during the period between 2011 and 2015, an amount of 28.165 Euros was sent in Romania via Western Union services. The amount collected by defendants constitutes the proceeds of crime committed by themselves in Italy.

De facto situation is proved through evidence gathered by technical means and administered in the penal case. The defendants invoked the exception of illegality of the investigation activities argued that they are illegal both from the point of view of the offence retained by prosecutor and their concordance with the act of indictment. On the one hand, regarding the illegal feature of the evidence administered in the penal case, the defendants requested from the judge of pre-trial court returning the case to the investigation phase as well as establishing nullity of the acts of intercepting private telephone calls due to the fact that, in accordance with the Constitutional Court decision no. 51/2016, they were carried out by the Romanian Service of Intelligence.

The defendants admitted during the investigation phase the court of law authorized actions of intercepting their telephone calls, but they were carried out by another state body than the investigation one. For this reason, the only one sanction applied for those actions is the nullity of the procedural acts carried out in such circumstances. This means that the evidence gathered by digital means of technical surveillance is null.

Considering from the constitutional point of view, the defendants emphasized that in the penal case Article 11 (2) Code of penal procedure on respecting the human dignity and private life was infringed. The pretrial judge appreciated that the role of this procedure is that of verifying the legality of evidence administered which "institutes the pre-trial judge's competence to verify the conformity of evidence administered during the investigation phase with the guarantees of the procedure fairness." ${ }^{2}$

The pre-trial judge stated there are vices of illegality. In this matter, the judge admitted the defendants' right to defense has been respected with its entire legal elements. They have been also informed on the offence committed the indictment act is based on as well as the offences legal integration, as premises for the fair trial.

52 Ibidem. 
Regarding the principle of legality and loyalty of administering evidence during the investigation phase, the pre-trial judge stated that the actions of technical surveillance lead with the Constitutional Court's decision and provision of Article 102 (3) Code of penal procedure due to the fact that they were carried out by another administrative body instead of the judicial one. Taking into account this aspect, the pre-trial judge stated that the defendants "indicated concretely neither what kind of interceptions they invoked the illegality with not what kind of nullity would affect these interceptions as being illegal ones in accordance with the Constitutional Court Decision no. 51/2016 they are prevailed with". ${ }^{3}$

\section{Case 2:}

In accordance with the Constitutional Court Decision no. $302 / 2017^{54}$ the legislative solution regulated by Article 281 (1/b) Code of penal procedure which does not provide the sanction of nullity in cases of infringing provisions regarding the investigation bodies' procedural competence rationae persone and rationae materie was declared unconstitutionally. Moreover, infringing provisions on executing procedural measures of technical surveillance including the other specialized state bodies' technical support is sanctioned by absolute nullity.

De iure, the pre-trial judge of the High Court of Cassation and Justice admitted the defendant's request and pre-trial exceptions regarding the illegality of the indictment act issued by the General Prosecutor Office attached to the High Court of Cassation and Justice - The National Anticorruption Directorate regarding the offences description and their legal integration as well as regarding the means of evidence administered..$^{55}$

53 Ibidem.

54 Decision no. 302 of 4 May 2017 of the Constitutional Court on the exception of unconstitutionality of Article 281 (1/b) Code of penal procedure, available online at: https://ccr.ro/files/products/Decizie_302_2017.pdf (accessed on 22 May 2019)

55 Conclusion no. 31/C of 27 September 2018 of the High Court of Cassation and Justice, available online at: https://www.scj.ro/1093/Detalii-jurisprudenta?customQuery\%5B0\%5D.Key=id\&customQuery\%5B0\%5D.Value $=147655$ (accessed on 24 March 2019) 
The indictment act contains the prosecutor's decision on the defendant's procedural status of being sent to trial for committing the tax evasion offence incriminated by Article 9 (1/c) and (3) of Law no. $241 / 2005^{56}$ and carrying out illegal financial operations as commercial activities by an incompatible person, incriminated by Article 12 (a) of Law no. $78 / 2000^{57}$.

The defendant appealed the pre-trial judge's conclusion arguing the fact that the fair trial principle is guaranteed through administering legal evidence. Moreover, defendant criticized the modality of administering evidence in the investigation phase from the point of view of the measures of technical surveillance illegality as exception also invoked by defendant.

The court of law observed that technical measures of surveillance having as object intercepting and recording telephone calls and communications as well as intercepting and audio-video recording the conversations discussed in the ambient environment and localizing and surveying by GPS were authorized in accordance with Article 138 Code of penal procedure. Initially, the provisions of Article 142 (1) Code of penal procedure regulates that "the prosecutor executes the technical surveillance order or can dispose it can be carried out by the investigation police body or specialized police officers or by the other state's specialized bodies". Once the Constitutional Court decision no. $51 / 2016$ entered into force the legal expression "or by the other state's specialized bodies" is unconstitutional.

The court of law admitted the defendant's request and disposed to the Prosecutor Office to specify "what the public authority executed the technical surveillance warrant in the current penal case and the implication of the Romanian Intelligence Service in the investigation activities, more particular what kind of these activities were carried out by the last institution". ${ }^{8}$ The prosecutor issued the official response which stated that the technical surveillance warrants disposed by the competent court

56 Law no. 241/2005 on preventing and combating tax evasion, published in the Official Journal no. 672 of 27 July 2005.

57 Law no. 78/2000 on preventing, discovering and sanctioning offences of corruption, published in the Official Journal no. 219 of 18 May 2000.

58 Conclusion no. 31/C of 27 September 2018 of the High Court of Cassation and Justice, available online at: https://www.scj.ro/1093/Detalii-jurisprudenta? 
of law have been executed with the technical support of the Romanian Intelligence Service "but the procedural reports of registering the results of technical surveillance activities have been drawn up in accordance with Article 143 Code of penal procedure by the judicial police officers within the Anticorruption National Directorate." ${ }^{59}$

Regarding the current investigation activity, it has been argued that the provisions of the Article 142 (1) Code of penal procedure were into force at the moment of disposing the special measures of technical surveillance both in the beginning and at the end of these activities. At the same time, the prosecutor pointed out that although the Romanian Intelligence Service was involved in the technical surveillance activities it did not carry out investigation activity during the investigation phase.

Taking into account the constitutional limitation in the penal case the legal provisions on carrying out the measures of technical surveillance have been infringed due to the fact that these activities were fulfilled by a state body having no competence in carrying out activities of investigation procedure. The situation produces the infringement of competence regulations that is sanctioned by absolute nullity. Moreover, in accordance with the Constitutional Court decision no. 302/2017 infringing the provisions of investigation bodies' competence is also sanctioned by absolute nullity, its legal effects being regulated by Article 281 Code of penal procedure.

Considering all these aspects stated above, the court of law decided removing the means of evidence and the supports that contain the result of the means of technical surveillance existed in the penal trial. At the same time, it stated removing all aspects related to these means of evidence and their content. For these reasons, the court of law admitted the defendant's appeal, repealed the conclusions invoked and declared the absolute nullity of the measures of technical surveillance. In accordance with Article 102 (2-4) Code of penal procedure, the court of law decided

customQuery\%5B0\%5D.Key=id\&customQuery\%5B0\%5D.Value=147655 (accessed on 24 March 2019)

59 Ibidem. 
to remove the procedural reports of registering the results of technical surveillance activities from the penal case. ${ }^{60}$

\section{Conclusions}

The criminality committed within the digital environment is the social phenomenon which refers to the diversity of criminal acts and activities the perpetrators commit. From a substantive penal law point of view, protecting such environment is carried out by special means of digital security ${ }^{61}$ Nevertheless, in the field of penal procedure law a particular regulation regarding the serious crimes is also necessary.

At present, the provisions regulated by the Code of penal procedure in Romania still creates difficulties in the judicial bodies' activity of achieving the scope of the penal trial consisting in finding the judicial truth based on legal evidence. The serious drawbacks existed in the judiciary must be corroborated with the constitutional limitation imposed on the illegal procedure of gathering digital evidence carried out by the other state's bodies than the investigation ones.

Taking into account these aspects, a set of de lege ferenda proposals has been identified and advanced in purpose to improve the legal framework of solving the cases in criminal matters.

Basically, having in view the major deficiencies of the penal procedure legislation into force, the proposals refer to the following aspects.

It is obviously that committing serious crimes $^{62}$, a special aggravated procedure is imperatively to be implemented in the justice

60 For the similar reference, see also Conclusion no. 31/C of 27 September 2018 of the High Court of Cassation and Decision, available online at: https:// www.scj.ro/1094/Detalii-dosar?customQuery\%5B0\%5D.Key=id\&customQuery\%5B0\%5D.Value=100000000316375

61 Alecu, Gheorghe; Barbaneagra, Alexei, Reglementarea penală și investigarea criminalistică a infractiunilor din domeniul informatic, Bucharest: Pinguin Book Publishing House, 2006, pp. 188-215.

62 Gounev, Philip; Ruggiero, Vincenzo, Corruption and Organized Crime in Europe. Illegal Partnerships, London and New York: Routledge Taylor and Francis Group, 2012, pp. 4-12; Campana, Paolo, Understanding Then Responding 
in criminal matters ${ }^{63}$, this kind of crimes to be solved on. The special procedure must be derogatory regulated from the ordinary penal procedure. It must regulate both the investigation and the judgment phases of penal trial. During the investigation phase, the main activity should take into account approaching the procedure of achieving:

- investigation of serious crimes, under the special aggravated procedure;

- aspects regarding the discovering, identifying, preserving, analyzing and administering digital evidence.

Among these activities, the legislator must focus its attention to administering digital evidence in order to regulate and implement it in the penal trial due to the fact that at present the Romanian legislation in criminal matters does not recognize de lege lata the possibility of administering digital evidence directly during the penal proceedings. ${ }^{64}$

\section{REFERENCES}

ALECU, Gheorghe; BARBANEAGRA, Alexei, Reglementarea penală și investigarea criminalistică a infractiunilor din domeniul informatic, Bucharest: Pinguin Book Publishing House, 2006.

BRITZ, Marjie T., Computer Forensics and Cyber Crime: An Introduction, New Jersey: Perason Education, 2013.

CAMPANA, Paolo, Understanding Then Responding to Italian Organized Crime Operations across Territories, Policing: A Journal of Policy and Practice, Vol. 7, Issue 3/2013, pp. 316-325, https://doi.org/10.1093/police/pat012

CONNERS, Kerry B., Warrants for Videotape Surveillance Issuable Despite Lack of Statutory Authority, St. John's Law Review: vol. 54, no. 4/1980, available online at: https://scholarship.law.stjohns.edu/cgi/viewcontent. cgi?article $=2418 \&$ context=lawreview (accessed on 18 May 2019)

to Italian Organized Crime Operations across Territories, Policing: A Journal of Policy and Practice, Vol. 7, Issue 3/2013, pp. 316-325.

Dusek, Libor, Time to punishment: The effects of a shorter criminal procedure on crime rates, International Review of Law and Economics, Vol. 43/2015, pp. 134-147.

64 Suian, Mihai, op. cit., p. 136. 
CONSTITUTION OF ROMANIA republished in the Official Journal of Romania, no. 669 of 22 September 2003, Bucharest: Themis Publishing House, 2003.

CONSTITUTIONAL COURT DECISIONS, Jurisprudence of admitting decisions, available online at: https://www.ccr.ro/jurisprudenta-decizii-de-admitere (accessed on 17 May 2019)

DUSEK, Libor, Time to punishment: The effects of a shorter criminal procedure on crime rates, International Review of Law and Economics, Vol. 43/2015, https:// doi.org/10.1016/j.irle.2014.04.007

GALETTA, Antonella The changing nature of the presumption of innocence in today's surveillance societies: rewrite human rights or regulate the use of surveillance technologies?, Belfast: European Journal of Law and Technology, Vol. 4, No. 2/2013, available online at: http://ejlt.org/article/view/221/377 (accessed on 14 May 2019)

GOUNEV, Philip; RUGGIERO, Vincenzo, Corruption and Organized Crime in Europe. Illegal Partnerships, London and New York: Routledge Taylor and Francis Group, 2012.

INTRODUCTORY GUIDE of Applying Legal Regulations regarding the Digital Criminality, Bucharest: INTERNEWS RITI dot-GOV, 2004, available online at: http://www.riti-internews.ro/ro/ghid.htm (accessed on 17 May 2019).

JAIDEV, Ms., Brady Ruling, 1963 U.S. Supreme Court: Sifting from being heard to open trial American and Indian Context, International Journal of Research, vol. 05, Issue 01/2018, available online at: https://journals.eduindex.org/index.php/ijr/ article/view/11807/11144 (accessed on 16 May 2019)

JURISPRUDENTA CEDO of Strasbourg, European Court of Human Rights, 2019. https://jurisprudentacedo.com/respectarea-vietii-private-si-familiale.html

LAW NO. 135/2010 on the Code of penal procedure of Romania, published in the Official Journal of Romania, no. 486 of 15 July 2010, entered into force on February 1, 2014.

MAGHERESCU, Delia, Recunoasterea vinovatiei si aplicarea pedepsei, Bucharest: Hamangiu Publishing House, 2019.

MICLEA, Damian, Cunoasterea crimei organizate, Ploiesti: Pygmalion Publishing House, 2001.

OLTEANU, Gabriel Ion; RUIU, Marin, Tectica criminalistica, Bucharest: AIT Laboratories Publishing House, 2009. 
REKHIS, Slim; BOUDRIGA, Noureddine, Visibility: A Novel Concept for Characterizing Provable Network Digital Evidences, International Journal of Security and Networks, No. 4/2009, available online at: https://www.researchgate.net/ publication/220080823_Visibility_A_novel_concept_for_characterising_ provable_network_digital_evidences (accessed on 21 May 2019)

SANCHEZ, Juan Carlos Ochoa, The Rights of Victims in Criminal Justice Proceedings for Serious Human Rights Violations, Brill/ Martinus Nijhoff, 2013.

SELEA, Mircea Mugurel, Application of the art. 102 (2) and (3) of the Criminal Procedure Code in relation to special surveillance measures listed under the art. 138 (1) (a) and (c) of the Criminal Procedure Code enforced before the publication in the Official Journal, Revista de Stiinte Politice, Craiova: Universitaria Publishing House, Issue no. 53/2017, available online at: https://cis01.central.ucv.ro/ revistadestiintepolitice/files/numarul53_2017/10.pdf (accessed on 21 May 2019).

SUIAN, Mihai, Unele probleme privind folosirea probelor digitale in procesul penal. Bucharest: Doctrina si Jurisprudenta, No. 1/2019.

SUN, Jia-Rong; SHIH, Mao-Lin; HWANG, Min-Shiang, A Survey of Digital Evidences Forensic and Cybercrime Investigation Procedure, Taichung: International Journal of Network Security, Vol. 17, No. 4, 2015, available online at: http://ijns.jalaxy. com.tw/contents/ijns-v17-n5/ijns-2015-v17-n5-p497-509.pdf (accessed on 21 May 2019).

TRECHSEL, Stefan; SUMMERS, Sarah J., Human Rights in criminal Proceedings, Oxford: Oxford University Press, 2009.

TULKENS, Francoise, The Paradoxical Relationship between Criminal Law and Human Rights, Journal of International Criminal Justice, vol. 9, Issue 3/2011, https://doi.org/10.1093/jicj/mqr028

UDROIU, Mihail; SLAVOIU, Radu; PREDESCU, Ovidiu, Tehnici speciale de investigare in justitia penala, Bucharest: C.H.Beck Publishing House, 2009. 


\section{Informações adicionais e declarações dos autores (integridade científica)}

Agradecimentos (acknowledgement): I would like to express my thanks to those professionals who helped me in carrying out the final version of my article, including the anonymous reviewers as well as the RBDPP Editorial Board who evaluated and accepted it in order to be published in the journal 2019 Special Issue.

Declaração de conflito de interesses (conflict of interest declaration): the author confirms that there are no conflicts of interest in conducting this research and writing this article.

Declaração de autoria e especificação das contribuições (declaration of authorship): all and only researchers who comply the authorship requirements of this article are listed as authors; all co-authors are fully responsible for this work in its entirety.

Declaração de ineditismo e originalidade (declaration of originality): the author assures that the text here published has not been previously published in any other resource and that future republication will only take place with the express indication of the reference of this original publication; she also attests that there is no third party plagiarism or self-plagiarism.

\section{Dados do processo editorial}

(http://www.ibraspp.com.br/revista/index.php/RBDPP/about/editorialPolicies)

- Recebido em: 11/06/2019

- Controle preliminar e verificação de plágio: 23/07/2019

- Avaliação 1: 27/07/2019

- Avaliação 2: 12/08/2019

- Decisão editorial preliminar: 26/09/2019

- Retorno rodada de correções: 29/09/2019

- Decisão editorial final: 29/09/2019
Equipe editorial envolvida

- Editor-chefe: 1 (VGV)

- Editora-associada: 1 (CC)

- Revisores: 2 


\section{COMO CITAR ESTE ARTIGO:}

MAGHERESCU, Delia. Using New Means of Technology during the Penal Proceedings in Romania. Revista Brasileira de Direito Processual Penal, Porto Alegre, vol. 5, n. 3, p. 1189-1217, set./dez. 2019. https://doi.org/10.22197/rbdpp.v5i3.250

\section{(c) $(1)(2)$}

Esta obra está licenciada com uma Licença Creative Commons Atribuição-NãoComercial 4.0 Internacional. 